Int. J. Dev. Biol. 53: 191-201 (2009)

doi: $10.1387 / \mathrm{ijdb} .082654 \mathrm{rf}$

\title{
Epigenetic asymmetry in the zygote and mammalian development
}

\author{
ROBERT FEIL* \\ Institute of Molecular Genetics, CNRS and University of Montpellier, Montpellier, France
}

\begin{abstract}
In mammals, the maternal and the paternal genome are not functionally equivalent and are both required for embryonic and postnatal development. The genome is organised differently in the oocyte as compared to sperm, in which the DNA is tightly packaged with protamines rather than with histones. The requirement of both the parental genomes for normal development is a consequence of differential epigenetic marking in oogenesis and spermatogenesis, at the regulatory elements that control genomic imprinting. These germ line-derived marks of DNA methylation are resistant to the global waves of demethylation that occur following fertilisation, and bring about the parental allele-specific expression of imprinted genes during development and after birth. Perturbation of the differential organisation of the maternally and paternally derived genomes, before fertilisation, or in the early embryo, can give rise to aberrant growth and developmental disorders in humans.
\end{abstract}

KEY WORDS: spermatogenesis, oogenesis, epigenetics, DNA methylation, imprinting

\section{Introduction}

In mammals, as opposed to other groups of animals, there is the requirement of both a maternal and a paternal genome for embryonic and foetal development. This raises the question as to how it comes that the maternal genome in the egg is not functionally equivalent to the paternal genome of the sperm. This is the theme of the current review, which discusses the organisation of the genome in sperm and oocytes, and how the maternal and paternal sets of chromosomes undergo genome-wide reprogramming after the formation of the zygote. As will be outlined below, differential organisation of chromatin at a subset of genes leads to these becoming expressed from only one of the two parental alleles. This epigenetic phenomenon is called 'genomic imprinting' and is a direct consequence of the sperm and egg being epigenetically non-equivalent. Disruptions in the epigenetic reprogramming of the genome in the male or female germ line, and in the way the parental genomes are remodelled during early development, can have long-lasting effects on development and well-being. Various developmental and clinical phenotypes have emphasized important pathological implications of the asymmetry between the parental genomes in mammals.

The first insight that both the parental genomes are required for normal development has come from the observation, in mice, that parthenogenetic embryos die in utero. These embryos have two maternal genomes, and no paternal genome (Graham, 1974). Elegant studies have shown that the developmental failure from not having both the parental genomes is due to the nuclear compartment, rather than the cytoplasmic one. Specifically, by transfer of male and female pronuclei directly following fertilisation of the egg, zygotes were constituted that had either two maternal pronuclei (gynogenotes), or two paternal pronuclei (androgenotes). These showed grossly abnormal development and did not proceed beyond day 10 of gestation (McGrath and Solter, 1984; Surani et al., 1984). Detailed studies on mice that were uniparentally disomic for individual chromosomes refined the notion that both the parental genomes are required for development to proceed to term (Cattanach and Kirk, 1985).

In mammals, there is a marked difference in the way the genomes are organised in the oocyte compared to sperm. Whereas

Abbreviations used in this paper:ART, assisted reproduction technology; BWS,
Beckwith-Wiedemann syndrome; DMR, differentially methylated region;
DNMT3A, DNA methyltransferase 3A; DNMT3L, DNMT3-like; H2AL,
histone H2A-like; ICR, imprinting control region; ICSI, intracytoplasmic
sperm injection; IUGR, intra-uterine growth restriction; ncRNA, non-
coding RNA; PGC, primordial germ cell; SRS, Silver-Russell syndrome;
TNDM, transient neonatal diabetes mellitus; UPD, uniparental disomy. *Address correspondence to: Dr. Robert Feil. Institute of Molecular Genetics, CNRS UMR-5535 and University of Montpellier II, 34293 Montpellier, France.
Tel: +33-467613663. Fax.: +33-46704-0231. e-mail: robert.feil@igmm.cnrs.fr - web: http://www.igmm.cnrs.fr

Published online: 27 April 2009.

ISSN: Online 1696-3547, Print 0214-6282

() 2009 UBC Press

Printed in Spain 
most of the structural differences between the maternal and the paternal genomes disappear during the first cell cycles after formation of the zygote, some persist, leading to the functional differences between the parental genomes. A hallmark feature which distinguishes the sperm genome from the egg genome is that it is globally compacted with protamine proteins rather than with histone proteins (Rousseaux et al., 2005; Kimmins et al., 2005; Sasaki and Matsui, 2008). It is during the final stage of spermatogenesis that a global exchange of the histone proteins for the more basic protamines takes place, and this leads to the exceptionally high compaction of the genomic DNA in sperm (Rousseaux et al., 2005). Directly following fertilisation, however, the protamines are removed and replaced by nucleosomal histones. These new histones acquire specific modifications after they are incorporated into the chromatin. Thus, globally, the paternal genome becomes nucleosomally organised shortly after fertilisation (as is the egg genome) and then undergoes many changes onto the newly-incorporated histones. An important question is whether all DNA in sperm is packaged with protamines, or whether certain sequence elements remain nucleosomally organised throughout spermatogenesis. The latter could have functional consequences, since these regions

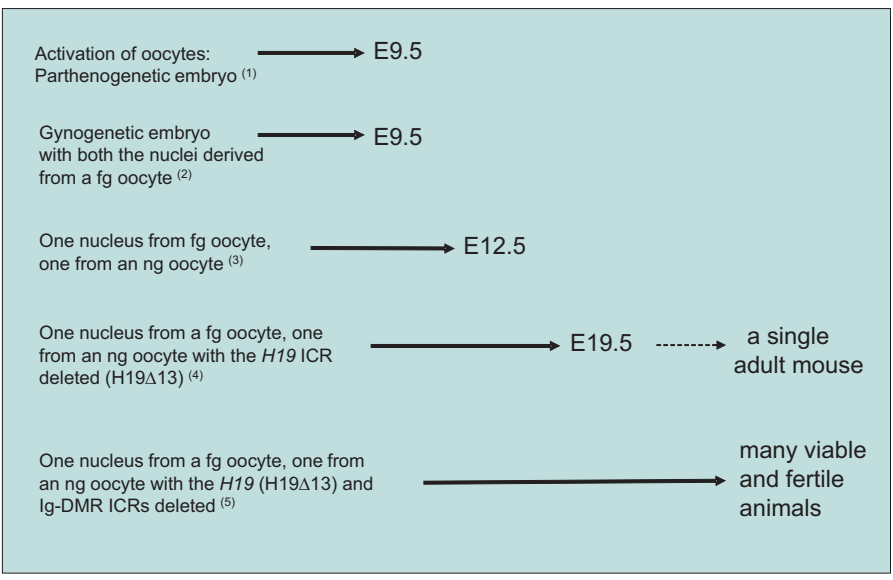

Fig. 1. Generation of mice with maternally-derived chromosomes only. Artificial activation of fully-grown oocytes leads to parthenogenetic development which, in the mouse, proceeds only to embryonic day 9.5 (E9.5) due to aberrant imprinting (with maternal imprints only). A similar phenotype is observed in gynogenetic embryos, which are derived by transfer of pronuclei after fertilisation. When using one genome from a fully-grown (fg) ocyte (with maternal imprints) and one from a nongrowing (ng) ocyte (with no maternal imprints yet), development proceeds a little further, till E13.5. Kono and co-workers $(2004,2007)$ showed that when they restored normal expression of the Igf2 gene (by deletion of the $\mathrm{H} 19$ ICR in the ng oocte) development proceeded even further, till birth, and, very rarely, till adulthood. Remarkably, when they restored normal expression levels at both the lgf2-H19 and the DIk1-GtI2 domains (by deletion of the two corresponding ICRs in the ng oocyte), many live-born animals were obtained that were viable and fertile. Combined, these studies indicate that the failure of parthenogenetic development is caused by the aberrant expression of genes at the paternally-imprinted domains (because of the absence of paternal imprints). These studies also show that sperm-derived proteins and RNAs are not required for full development to term. The format of this figure was adapted from Kono, 2006. 1, Surani and Barton, 1983; Sturm et al. 1994; 2, Suraniet al., 1983; 3, Kono et al., 1996; 4, Kono et al. 2004, 2006; 5, Kawahara et al., 2007. would possibly not undergo the global re-organisation into nucleosomal chromatin following fertilisation.

From studies in different mammalian species it has become evident that the sperm genome undergoes active demethylation shortly after fertilisation of the egg. This is brought about by yetunknown factors present in the egg's cytoplasm. The process is thought to occur directly after the removal of the protamines and the incorporation of histones into the chromatin. The maternal genome is not subject to this active demethylation process, but undergoes a passive loss of DNA methylation during pre-implantation development, such that at the blastocyst stage, it becomes largely unmethylated (Reik et al., 2001). Not all DNA sequences undergo active (paternal genome) and passive (both genomes) removal of DNA methylation. This raises the question as to why certain DNA sequences are protected against the global waves of DNA demethylation. Unravelling what protects these exceptional regions against demethylation after fertilisation, and against the acquisition of new DNA methylation at later developmental stages, may provide novel insights into the asymmetry between the parental genomes in mammals.

\section{The functional non-equivalence of the parental ge- nomes}

In different groups of animals, parthenogenesis is compatible with normal development to adulthood. In different bird species, including chickens and turkeys, healthy adult animals have been obtained by parthenogenesis through spontaneous activation of the egg (Olsen, 1961; Sarvella, 1973). Also in several insect species, such as in aphids, parthenogenesis is commonly observed, as a means of asexual reproduction (Hales et al., 2002). Furthermore, parthenogenesis is suspected to sometimes give rise to live-born offspring in different species of snakes, and has been observed in sharks in captivity as well (Groot et al., 2003; Edwards, 2007).

In mammals, in contrast, parthenogenesis is not compatible with normal development (Fig. 1). Parthenogenetic mouse conceptuses, obtained by artificial activation of oocytes, develop till about mid-gestation only. They show gross developmental abnormalities, including reduced embryo size and an almost complete lack of placental tissues (Graham 1974; Surani and Barton, 1983; Mann and Lovellbadge, 1984). Such monoparental embryos can be obtained by nuclear transplantation as well, immediately following the fertilization of the egg by the sperm. By replacing the male pronucleus by a female one, for instance, so-called gynogenetic embryos can be obtained (carrying two maternal genomes). Developmentally, these are similarly affected as the parthenogenetic embryos due to the absence of a paternal genome (Surani and Barton, 1983). Androgenetic embryos have two paternal genomes, and no maternal genome, and show a completely different phenotype. Whereas their extra-embryonic membranes are relatively normal, the embryo proper is retarded and progresses rarely beyond the four to six-somite stage (McGrath and Solter, 1984; Surani et al., 1984). Similar phenotypes have been observed in a ruminant species, the sheep (Feil et al., 1998; Hagemann et al., 1998). Combined, the studies in different species established that both a maternal and a paternal genome are required for mammalian development to proceed to term.

From studies during the last few years, it seems that the 


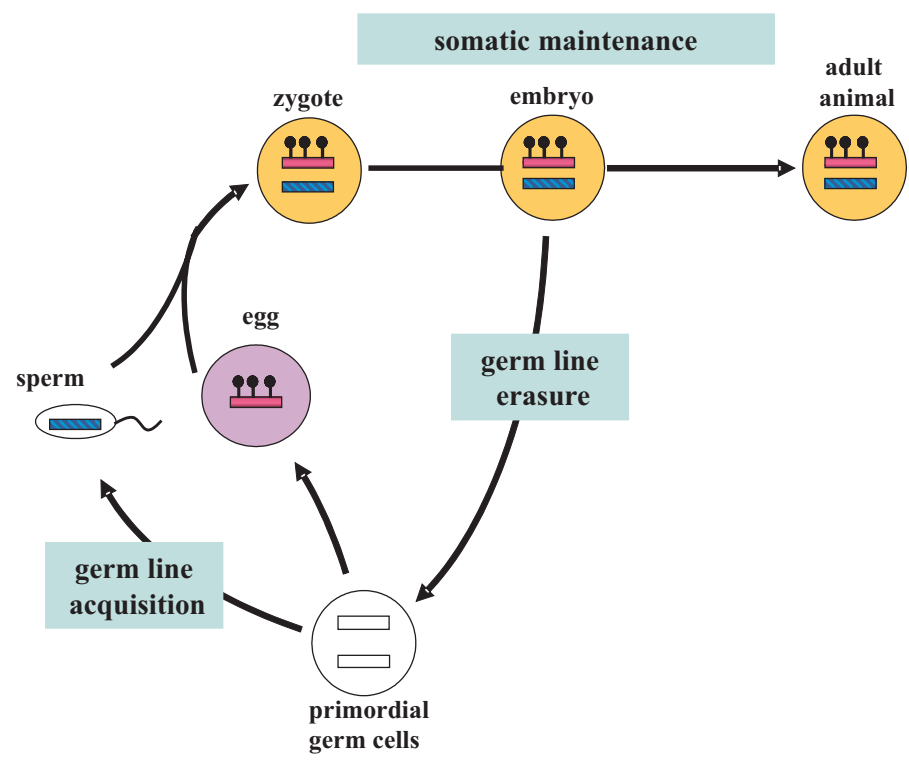

Fig. 2. The developmental cycle of DNA methylation at imprinted gene loci. Methylation imprints are established at individual imprinting control regions (ICRs) during either oogenesis, or spermatogenesis. Specifically, some ICRs have the maternal imprints, which are established during oogenesis, after the first meiotic division, in growing oocytes. Only a few ICRs have patenal imprints. These are established during spermatogenesis, before meiosis, at a foetal stage of development. After fertilisation of the egg by the sperm, the allelic methylaton imprints at ICRs are maintained in all somatic lineages throughout development. Shown is one example, of an ICR which acquires its methylation in the female germ line. The DNA methylation imprint (black lollypops) is indicated. In the newly-formed primordial germ cells (PGCS) of the developing embryo, there is erasure of the methylation imprint, to allow novel imprints to be established subsequently for the next generation.

aberrant phenotypes of androgenetic and parthenogenetic conceptuses are caused by certain genes that are expressed from the maternal or the paternal genome only (Fig. 1). The differential expression of genes according to their parental origin is called 'genomic imprinting' (Fig. 2) and will be discussed below.

\section{Differential chromatin remodelling after fertilisation}

At the time of fertilisation, the sperm and egg genomes are differently organised, as a consequence of the differential epigenetic reprogramming during male and female gametogenesis (Sasaki and Matsui, 2008). The paternal genome in the sperm is haploid and is packaged with protamines. The egg, in contrast, is diploid at fertilisation (with one genome present in the extruded first polar body) and its genome is packaged with nucleosomes. Although the oocyte completes meiosis only following fertilisation, with extrusion of the second polar body, its genome remains nucleosomally organised throughout. At the sperm genome, in contrast, following fertilisation there is a rapid replacement of protamines by histone proteins (Morgan et al., 2005). Protamineto-histone substitution precedes the apparently genome-wide loss of DNA methylation that is observed specifically at the spermderived paternal pronucleus, several hours following fertilisation.
Interestingly, this demethylation occurs before the onset of replication leading to the first cell division, and is therefore thought to be an active process. The process has been observed most clearly in mouse studies, but has also been reported to occur in humans, cattle and other mammalian species (Mayer et al., 2000; Oswald et al., 2000; Barton et al., 2001; Dean et al., 2001; Fulka et al., 2004). It remains to be confirmed, however, to which extent this demethylation process is conserved in all groups of mammals (Beaujean et al., 2004; Shi et al., 2004; Lepikhov et al., 2008), and what could be its biological role. Studies are also required to more comprehensively assess the range of sequences that become demethylated.

Which enzymatic factors are involved in the active removal of DNA methylation from the paternal genome is not known, but candidate mechanisms have been discussed, including glycosylation occurring specifically at methylated cytosines followed by a DNA repair process with inclusion of non-methylated cytosines (Morgan et al., 2004). From several studies, it appears that the active demethylation occurs in the context of DNA which is (becoming) nucleosomally organised, at a point in time however at which histone modifications are still grossly different at the paternal and maternal pronuclei (Adenot et al., 1997; Santos et al., 2002; Erhardt et al., 2003). It is unknown what protects the maternal genome against the active process of demethylation, but this could well be related to the fact that its core histones are marked by different modifications than on the paternal genome. During the pronuclear stages that follow fertilisation, it has indeed been observed for several histone modifications that they display pronounced differences in the maternal and the paternal pronucleus. For instance, whereas $\mathrm{H} 3$ lysine-9 (di and tri) methylation is strongly detected at the maternal pronucleus, at the early pronuclear stages, it is virtually absent from the paternal pronucleus. The same was reported for $\mathrm{H} 3$ lysine 27 di and trimethylation (Erhardt et al., 2003; Morgan et al., 2005; van de Heijden et al., 2005). H3 lysine-9 methylation, possibly in combination with other methylation marks, such as $\mathrm{H} 3 \mathrm{~K} 27$ methylation, could protect the genome against the active process of DNA demethylation. Although such a protective mechanism is still to be demonstrated, it is interesting to note that some sequences do not undergo active demethylation on the paternal genome, and chromatin at these regions seems to be enriched in $\mathrm{H} 3$ lysine-9 methylation (Lepikhov and Walter, 2004; Santos et al., 2005).

Another element that could be important is that the new histones on the paternal genome are incorporated before DNA replication occurs. Some of these incorporated histones are therefore thought to be non-canonical replacement variants. The best studied of these is $\mathrm{H} 3.3$, an $\mathrm{H} 3$ variant which is incorporated into the chromatin independently of DNA replication by a mechanism using specific chaperone proteins including the assembly factor HIRA. Interestingly, H3.3 shows a dynamic distribution in the mouse oocyte and the early embryo, with a preferential incorporation into the paternal pronucleus following fertilisation (van der Heijden et al., 2005; Torres-Padilla et al., 2006). Whether replacement histone variants such as $\mathrm{H} 3.3$ are involved in steering the subsequent active DNA demethylation process, is unknown, but this would represent another putative mechanism that could provide specificity to the process and explain why the maternal genome is protected against loss of methylation at this post-fertilisation stage. 
Finally, it is likely that specific non-histone proteins produced during oogenesis and early development participate in the protection against the active DNA demethylation following fertilisation. One such a protective maternal protein has been identified so far. It is Stella (also called PGC7), a protein with a SAP domain (scaffold attachment factor/acinus/PIAS) which is expressed in primordial germ cells, in oocytes, and in pre-implantations embryos. Initial studies had shown that maternal deletion, leading to lack of the protein in the oocyte, has a strong maternal effect with embryos rarely reaching the blastocyst stage (Payer et al. 2003). Interestingly, a recent study shows that Stella is important for the epigenetic asymmetry in the zygote and protects the DNA methylation state at several imprinted gene loci. Specifically, Stella protects the maternal genome against demethylation after the protein becomes localised to the female pronucleus, where it protects several of the maternal "imprinting control regions" (see below) against demethylation. The protective mechanism remains to be uncovered though, but may involve direct binding of Stella/PGC7 to the chromatin given that the protein has a high binding affinity to DNA (Nakamura et al. 2007).

Of particular importance relative to the paternal pronucleus is
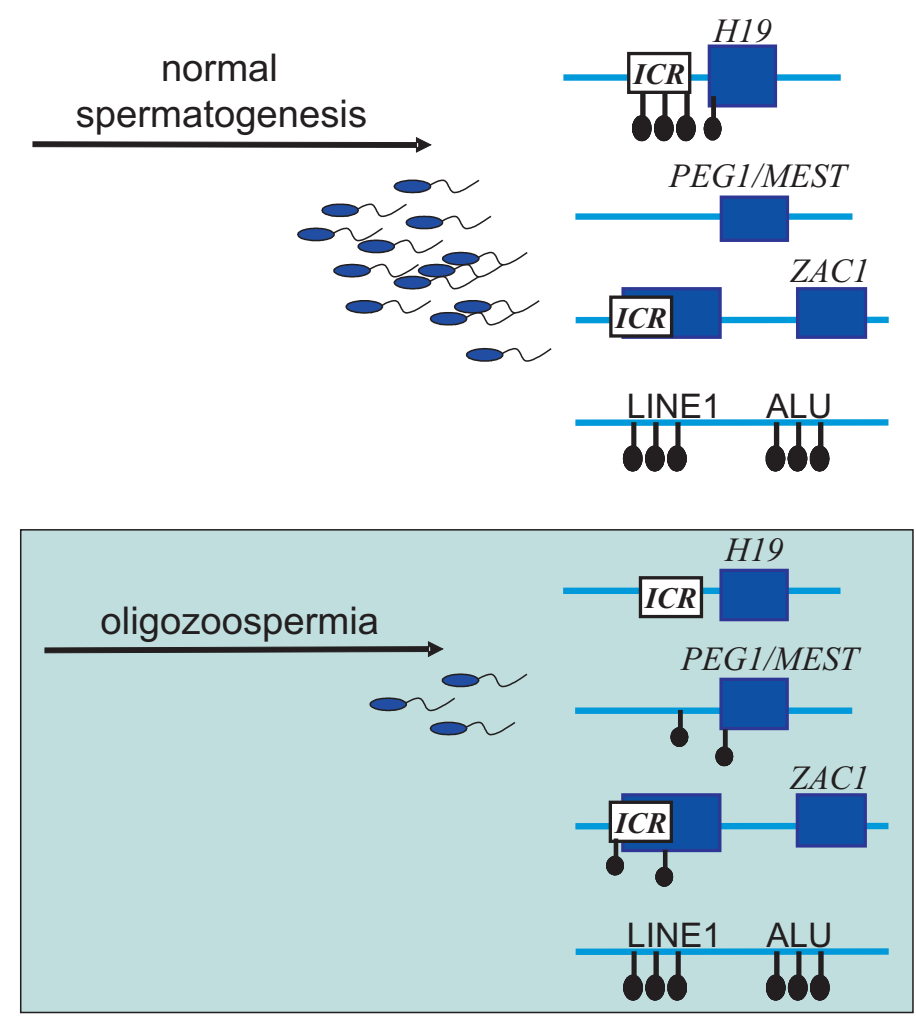

Fig. 3. Altered methylation patterns at imprinting control regions in sperm of oligospermic men. Oligozoospermia is characterised by a strongly reduced concentration of spermatozoa in sperm. In several recent studies (Marques et al. 2004, 2008; Kobayashi et al. 2007), cases were identified in which the reduced sperm counts were associated with a high frequency of altered DNA methylation at imprinting control regions (ICRs). Loss of methylation was observed at the IGF2-H19 ICR. The ICRs controlling the ZAC and PEG 1/MEST imprinted lociare fully unmethylated in normal sperm, but showed frequent gain of methylation in sperm of oligospermic men. Interestingly, unaltered levels of DNA methylation were observed at LINE1 and ALU repeat elements. the discovery that not the entire genome is subject to the active removal of methylation following fertilisation. For instance, the satellite DNA sequences of the compacted chromatin surrounding centromeres and also certain intracisternal-A particle (IAP) retrotransposons seem to be relatively resistant to demethylation (Rougier et al., 1998; Lane et al., 2003). Why the DNA of heterochromatin does not lose its methylation is unknown. To address this key question, it should be important to unravel its organisation in mature sperm. Amongst other questions, it should be pertinent to determine whether the pericentric regions are packaged with protamines, or rather, have a nucleosomally organised structure in sperm. Given the highly compacted state of the genome in mature sperm, this question has been extremely difficult to address. One preliminary study in which human sperm was decompacted with different concentrations of salt has attempted to address this question, and it reported that the imprinted locus comprising the Insulin-like growth factor-2 (IGF2) gene (Fig. 3) had a relative enrichment in histone-compacted DNA (Wykes and Krawetz, 2003). Other studies have taken another angle, and explored the process of spermiogenesis, the final stages of male germ cell development during which the global histone-to-protamine exchange takes place (Govin et al., 2007; Delaval et al., 2007). At these specific stages, there is expression of certain histone variants that are only present during spermatogenesis (Govin et al., 2004; Rousseaux et al., 2005; Kimmins and Sassone-Corsi, 2005). Elegant recent work shows that two histone $\mathrm{H} 2 \mathrm{~A}$ variants, H2A-like 1 and 2 (H2AL1 and 2), become specifically incorporated into heterochromatin at the elongating spermatid stage and that this correlates with the formation of an unusual, nucleosome-like, structure (Govin et al., 2007). This remarkable finding raises the possibility that besides specific histone modifications, also the incorporation of specialised histone variants could impact on whether or not a chromosomal region undergoes histone-to-protamine exchange. Whether the non-canonical nucleoprotein structures comprising H2AL1 and H2AL2 persist in mature sperm, and whether they interfere with the DNA demethylation occurring after fertilisation, remains to be explored.

\section{Imprinting control regions resist reprogramming after fertilisation}

To date, some eighty genes have been identified to be subject to genomic imprinting in mammals. Many these play key roles in foetal growth development, whereas others are involved in postnatal fitness and behaviour (Morison et al., 2005). Imprinted genes are organised in chromosomal domains, which are broadly conserved between mice and humans. Imprinted domains are unusual in that the specific sequence elements which control their expression are marked by mono-allelic DNA methylation. These so-called 'imprinting control regions' (ICRs) convey the parental allele-specific expression of imprinted genes (Li et al., 1993). Specifically, ICRs are elements of up to several kilobases in size that are rich in $\mathrm{CpG}$ dinucleotides. Many correspond to $\mathrm{CpG}$ islands (Hutter et al., 2006; Kobayashi et al., 2006). At most ICRs, the allelic methylation is established during oogenesis. This occurs in the adult animal at a late stage of oogenesis, during the growth and maturation of the oocyte, and coincides with global chromatin condensation and the shut-off of transcription (Obata 
et al. 2002; Lucifero et al. 2004). At only three of the known ICRs in the mouse, methylation is established during spermatogenesis. Acquisition of methylaton imprints in this germ line occurs at late foetal stages, before the onset of meiosis, and coincides with a genome-wide increase in DNA methylation (Schaefer et al., 2007; Oakes et al. 2007). After the establishment of the methylation marks at ICRs, in either the female or the male germ line, these imprints are maintained during the subsequent development of the germ cells. Consequently, some ICRs are methylated in the mature oocyte, and not in spermatozoa (Fig. 2). Others are methylated in sperm only. The DNA methyltransferase DNMT3A, together with a DNMT3-like protein, DNMT3L, is required for putting new methylation imprints onto the ICRs (Bourc'his et al., 2001; Hata et al., 2002; Kaneda et al., 2004). It remains to be discovered why at some ICRs this occurs in the female germ line only, whereas at others, acquisition of methylation occurs in the male germ line only. Possibly, the 'choice' could relate to the finding that ICRs that acquire their DNA methylation in the oocyte correspond all to promoter regions, whereas the sperm-methylated ICRs are not promoters and are located many kilobases away from genes. Paternal ICRs are also less rich in CpG dinucleotides than the maternal ICRs (Kobayashi et al.2006). For some ICRs it was found that, besides the ICR itself, close-by sequences are essential for the germ line specific establishment of their DNA methylation. This raises the possibility that specific DNA binding proteins could be involved by interacting with the ICR and nearby sequences (Yoon et al., 2002; Perk et al., 2002). Interestingly, for two of the paternal ICRs, a recent in vitro study suggests that the zinc-finger protein CTCF-like (also called BORIS), expressed during spermatogenesis only, could be involved in the establishment of their methylation imprints (Jelinic et al. 2006). Finally, it seems important to note that many of the ICRs comprise imperfect tandemly-repeated sequences, of which the significance in imprint establishment remains to be discovered (Hutter et al., 2005).

Imprinted domains are thus far the only endogenous chromosomal regions at which there is differential DNA methylation between the sperm and the egg. Importantly, in the context of this review, all ICRs are fully resistant to the chromatin remodelling that occurs after fertilisation (Fig. 2). Later in development, they induce parental allele-specific expression at nearby genes (Delaval and Feil, 2004). It is because of the imprinting mechanism that the maternal and the paternal genome are functionally different (Latham et al., 1994; Kono et al., 2004; Niwa et al., 2005; Kowahara et al., 2007). In placental mammals, therefore, there is an absolute requirement for normal embryonic and postnatal development to have both a maternally and a paternally derived genome. As mentioned earlier in the text, having just maternal, or paternal, genomes leads to gross developmental abnormalities due to the aberrant expression of imprinted genes. So far, more than eighty imprinted genes have been discovered in the mouse. Many of these show expression from only one of the two parental alleles in humans as well. Several imprinted genes play key roles in cellular proliferation and growth of the embryonic and extraembryonic lineages, whereas others influence postnatal fitness and behaviour (Morison et al., 2005). Imprinted genes are organised in chromosomal domains, each of which comprises an ICR that controls the allele-specific expression of the domain's genes. How, precisely, the differentially methylated ICRs bring about the allelic gene expression of nearby genes, differs between different imprinted domains. At some domains, on its nonmethylated allele the ICR transcribes a non-coding RNA (ncRNA) which conveys chromatin repression in cis during early development. At other domains, the ICR brings about an allelic chromatin configuration which prevents the activation of promoters by distant enhancer sequences. The different scenarios via which the epigenetic imprints at ICRs are 'read' and interpreted to give rise to allelic expression of nearby genes are not presented in this review, but are discussed in detail elsewhere (Delaval and Feil, 2004; Edwards and Ferguson-Smith, 2007; Pauler et al., 2007).

The insight that the egg and sperm have a different epigenetic regulation had emerged several years before the discovery of the first imprinted genes, based on studies on transgenes. Swain and co-workers (1987) provided a first indication of a parent-of-origin specific effect on the expression and methylation of a transgene. They had a mouse transgene in which the LTR from the Rous sarcoma virus was linked to $c M y c$. This transgene was found to be unmethylated and expressed upon paternal transmission, but was methylated and silent upon maternal transmission. It was shown subsequently, that the methylation reprogramming of this 'imprinted' transgene, and hence the reprogramming of its transcription potential, occurred in the primordial germ cells of the developing gonads (Chaillet et al., 1991). Other transgenic constructs were found to be subjected to parent-of-origin specific DNA methylation and gene silencing as well (Reik et al., 1987), indicating that the transgene at the insertion site conveyed differential epigenetic regulation. The first endogenous imprinted genes that were shown to have such an unusual behaviour were the Insulin-like growth factor 2 (Igf2) (DeChiara et al., 1991), the Igf2receptor gene (Igf2r) (Barlow et al., 1991), and the ncRNA H19 gene located close to Igf2 (Bartolomei et al., 1991).

Methylation imprints at ICRs are maintained in all somatic cells throughout development (Fig. 2). During preimplantation development, this maintenance involves both the maternal and the somatic form of DNA methyltransferase-1 (Dnmt1) (Kurihara et al., 2008; Hirasawa et al., 2008). Strikingly, ICRs are not subject to the global waves of DNA demethylation following fertilisation, and do also not acquire novel DNA methylation during and after implantation of the embryo in the uterus. This full protection against epigenetic changes is most remarkable for the three known ICRs which have paternal DNA methylation. These ICRs acquire their DNA methylation in pre-meiotic spermatogenic cells. Similarly as for methylation at pericentric heterochromatin, these methylation imprints persist to mature sperm, and are protected against the global waves of DNA demethylation after fertilisation of the egg (Olek and Walter, 1997). How paternally methylated ICRs are organised in mature sperm is not known and this makes it difficult to speculate on what might provide their specific protection. However, during early spermatogenesis the paternally imprinted regions are associated with different histone methylation patterns than the ICRs that are methylated in the oocyte. Particularly, chromatin at the paternal ICRs is devoid of histone H3 lysine-4 methylation (Delaval et al., 2007). This covalent H3 modification is thought to be important in the protection against DNA methylation, by preventing recruitment of the DNMT3LDNMT3A protein complex (Ooi et al., 2007). After the first cell division, and at later stages of embryonic development, when the maternal and the paternal genomes become nucleosomally 
organised in a similar way (Morgan et al., 2005), ICRs are protected against changes in DNA methylation as well. It is not understood how it comes that the methylated allele of the ICR remains methylated throughout development, whereas the unmethylated is protected against de novo methylation. However, the chromatin organisation at the methylated allele was found to be comparable to that at pericentric heterochromatin (Martens et al. 2005; Delaval et al., 2007), which shows constitutive maintenance of DNA methylation as well. Particularly, DNA methylation at ICRs is associated with chromatin that has constitutive $\mathrm{H} 3$ lysine- 9 di and trimethylation and $\mathrm{H} 4$ lysine-20 trimethylation, and a consistent absence of H3 acetylation (Vu et al., 2004; Wu et al., 2006; Delaval et al., 2007; Regda et al., 2007). The unmethylated alleles of ICRs, in contrast, are always associated with H3 lysine4 methylation (Fournier et al., 2002; Umlauf et al., 2004; Delaval et al., 2007), a mark which could prevent acquisition of new DNA methylation by interfering with the binding of the DNMT3ADNMT3L complex (Ooi et al., 2007). One of the challenges will be to unravel which histone methyltransferases are involved in the differential histone methylation at ICRs and how these could be involved in the imprinting process (Pannetier et al., 2008).

\section{Pathological disruption of parental chromatin organisation}

The methylation asymmetry becomes established during spermatogenesis and oogenesis (Fig. 2). This raises the question of whether defects in gametogenesis could interfere with the epige- netic marking of the male and female gametes. Several recent studies demonstrate for spermatogenesis, that this is indeed the case. Oligospermic men produce sperm which is often morphologically normal, but sperm counts are severely reduced and this is associated with infertility. An initial study (Marques et al. 2004) on twenty five moderate to severe cases described that about one-fourth of these men had abnormal patterns of methylation at the imprinted IGF2 domain at which the ICR has sperm-derived DNA methylation. In the oligospermic patients, the sperm showed Ioss of DNA methylation at specific CpG dinucleotides of this ICR (Marques et al., 2004, 2008). This finding indicates a potential risk of transmitting perturbed imprinted IGF2 and H19 expression to the next generation. This conceptually important finding was confirmed recently in a study of 97 infertile men, in which DNA methylation was analysed at seven imprinted loci (Kobayashi et al., 2007). Abnormal paternal methylation imprints were detected in $14 \%$ of patients in this cohort. Cases were identified in which there was an almost complete absence of DNA methylation at the IGF2-H19 ICR in sperm. Interestingly, this and another study (Marques et al., 2008) revealed abnormal imprints at maternal ICRs as well, with varying degrees of methylation at several ICRs that are normally not methylated in sperm (Fig. 3). These epigenetic defects are most likely specific to imprinted genes, since levels of DNA methylation at LINE-1 and ALU repeat sequences were unaltered (Fig. 3). Interestingly, it was noted in one of the studies that the outcome of assisted reproduction by intra-cytoplasmic sperm injection (ICSI) was poor when sperm from these oligospermic males was used. However, so far, no cases have
A

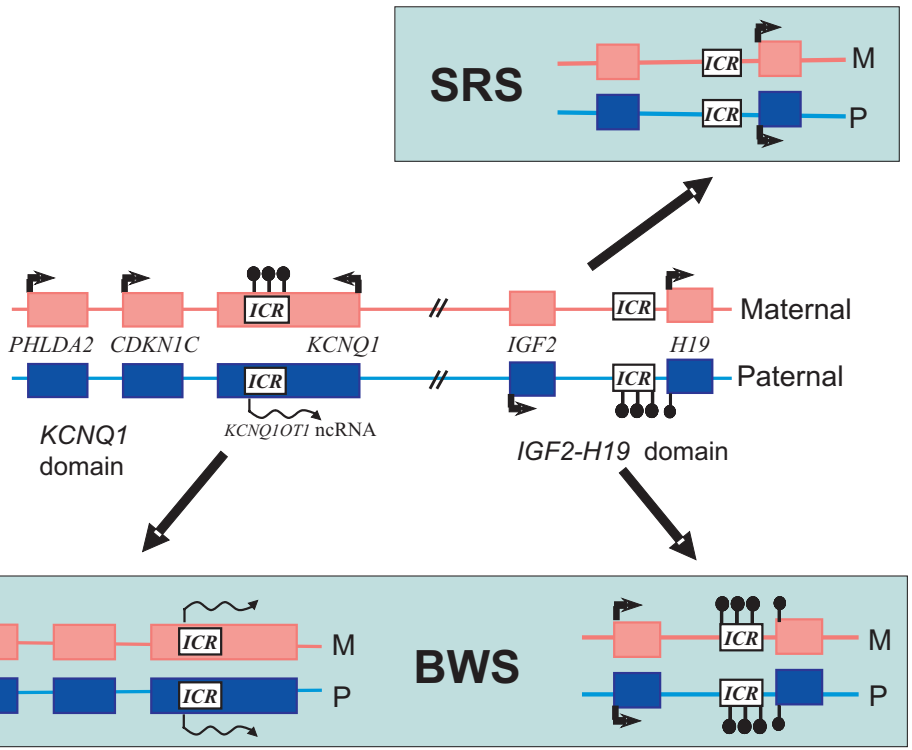

B

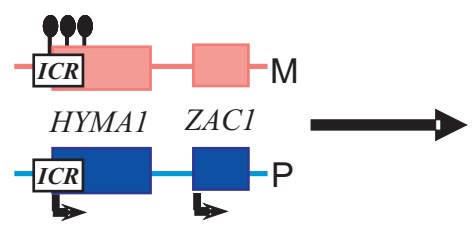

ZAC domain

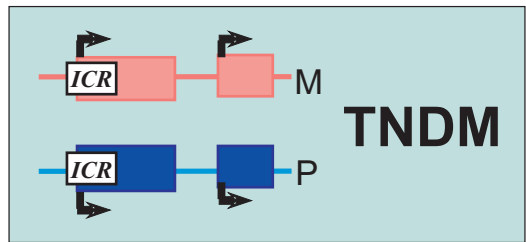

Fig. 4. Altered parental imprints in human perinatal disorders of aberrant growth. (A) Loss of imprinting at human chromosome 11p15 in Silver-Russell Syndrome (SRS) and Beckwith-Wiedemann Syndrome (BWS). The H19 ICR lopen box) is methylated (lollipops) exclusively on the paternal allele $(P)$ and conveys paternal expression of the IGF2 growth-factor gene, and maternal expression of the $\mathrm{H} 19$ gene. SRS is characterised by reduced foetal growth and in about half of the patients, there is loss of methylation at the $\mathrm{H} 19$ ICR. This causes a strong reduction in IGF2 expression, and biallelic expression of $\mathrm{H} 19$. The opposite epimutation is observed in ten percent of patients with the foetal overgrowth syndrome BWS. Here, biallelic methylation at the $\mathrm{H} 19$ ICR (and H19) causes biallelic IGF2 expression. The ICR regulating the flanking KCNO1 domain is methylated only on the maternal allele (M). On the unmethylated paternal allele, it produces an ncRNA (KCNQ1OT1) that mediates repression on the paternal chromosome. The KCNQ1 domain encompasses the negative growth regulator CDKN1C, and PHLDA2, a placental gene whose expression is perturbed in intra-uterine growth restriction (McMinn et al. 2006).. In half the BWS patients, there is loss of methylation at the ICR. This correlates with biallelic expression of the ncRNA, and biallelic repression of genes along the domain, including that of CDKN1C. (B) Loss of imprinting in Transient Neonatal Diabetes Mellitus (TNDM). The imprinted ZAC and HYMA1 genes on chromosome 6q24 are regulated by a putative ICR, which is methylated (Iollipops) on the maternal allele (M) only. In TNDM, there is loss of DNA methylation. This causes biallelic ZAC expression and TNDM, a syndrome frequently associated with intra-uterine growth restriction. 


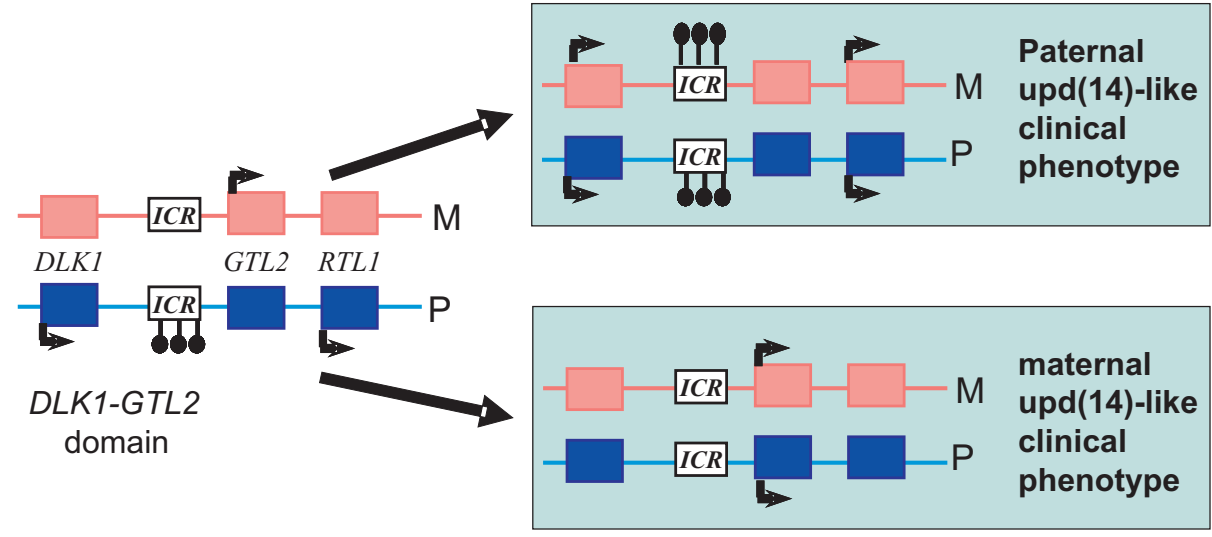

Fig. 5. Perturbed germ line imprints at the GTL2-DLK1 domain on human chromosome 14q32. The DLK1-GTL2 domain comprises both maternally and paternally expressed genes that are associated with specific developmental phenotypes (Kagami et al. 2008). The domain is controlled by an intergenic ICR which has sperm-derived DNA methylation. A recent study identified patients that had a clinical phenotype that was comparable to that observed in paternal UPD of chromosome 14 (including the occurrence of a bell-shaped thorax), but in whom there was no evidence for genetic alterations. In these rare patients, there was biallelic DNA methylaton at the ICR, leading to over-expression of paternally expressed genes (Kagami et al., 2008). The opposite epigenetic change has been reported relative to a clinical phenotype similar to that observed in maternal UPD for chromosome 14.

been reported of children born after ICSI who had an imprintingrelated disorder, or displayed aberrant DNA methylation at ICRs (Kobayashi et al., 2007). It also remains to be discovered how defects in the production of spermatozoa could be mechanistically linked to the methylation status of ICRs in sperm. Besides the specific methylation changes in compromised spermatogenesis, it was discovered recently that there is considerable intraand inter-individual variation in methylation patterns in sperm samples from fertile men (Flanagan et al., 2006). Some of these variations could be due to an incomplete erasure of DNA methylation in the early germ cells (were methylation is normally completely erased), as observed at the mouse Agouti variable yellow ( $A^{v y}$ locus (Morgan et al., 1999). In addition, it was shown in this experimental model that nutritional supplementation with methyl donors can readily lead to altered methylation patterns in the sperm (Cropley et al., 2006). It should be important, therefore, to further explore the influence of dietary and environmental factors (Feil, 2006; Jirtle and Skinner, 2007) on methylaton patterns in sperm, and to determine the possible consequences for the next generation.

Whether similar effects on DNA methylation occur during oogenesis is unknown. However, oocytes are produced early in life and are maintained in a non-mature state till fertilisation, which can be at quite an advanced age in humans. Although genetic defects are known to accumulate in oocytes with age, it remains to be explored if also epigenetic changes are likely to occur upon ageing, a question which could be particularly relevant for imprinting loci.

Several aberrant growth and developmental disorders in humans are caused by perturbation of methylation imprints at ICRs, and are thought to arise during the early stages of development (Fig. 4A). The underlying mechanisms are unknown, but these diseases could be linked to the parental genomes' reprogram- ming which occurs after fertilisation and during the pre-implantation stage of development (reviewed in Arnaud and Feil, 2005; Delaval et al., 2006). Possibly, methylation patterns are not yet firmly fixed during early development in the non-committed cells, as they are in differentiated cells.

Silver-Russell Syndrome (SRS) is a mostly sporadic congenital disorder, characterised by intra-uterine and postnatal growth restriction, facial dysmorphism and minor, less frequently observed, abnormalities. Several recent studies on SRS show that in about half of the patients with this rare disease, there is loss of DNA methylaton at the ICR regulating IGF2 and H19 on chromosome 11p15 (Gicquel et al., 2005; Eggermann et al., 2006; Bliek et al., 2006). This leads to an almost complete loss of expression of IGF2, and therefore reduced levels of this major growth factor, which explains the observed growth retardation (Fig. 4A).

Beckwith-Wiedemann Syndrome (BWS) is another rare congenital disorder that affects growth and is linked to chromosome 11p15. This mostly sporadic disease presents an opposite phenotype compared to SRS, with pre- and post-natal overgrowth, and developmental defects including macroglossia, abdominal wall defects, and organomegaly. In BWS, there is an increased risk of Wilms' tumour of the kidney as well. Interestingly, in about $10 \%$ of the patients with BWS there is the exact opposite epigenetic alteration at the IGF2-H19 ICR as the one occurring in SRS. This class of BWS patients shows gain of DNA methylation at the ICR, on the parental allele which is normally not methylated. This methylation change leads to biallelic expression (and a double dose) of IGF2, which explains the observed foetal overgrowth. BWS can arise not only from epigenetic alterations at the ICR controlling IGF2, but also by altered DNA methylation at the ICR which regulates the growth-related $K C N Q 1$ domain next to the IGF2-H19 locus. In about half of the patients, there is loss of methylation at this intronic ICR controlling the KCNQ1'imprinted domain (Fig. 4A). This early-embryonic loss of methylation correlates with reduced expression (i.e., biallelic repression) of the CDKN1C gene located in the domain (Lee et al., 1999; Smilinich et al., 1999; Diaz-Meyer et al., 2003). The loss of expression of this anti-proliferative protein is involved in the BWS syndrome in this subgroup of patients.

Epigenetic deregulation of imprinting is causally involved in transient neonatal diabetes mellitus (TNDM) as well (Fig. 4B), a rare congenital disease associated with intrauterine growth retardation, dehydration and lack of insulin. The disease involves an imprinted locus comprising the paternally expressed $Z A C$ gene on chromosome $6 q 24$. This locus is regulated by a putative ICR which has maternal methylation. In the majority of patients with TNDM, there is early embryonic loss of methylation at this ICR leading to biallelic expression of ZAC (Gardner et al., 2000; Varrault et al., 2001; Arima et al., 2001). Interestingly, the ZAC transcription factor regulates the expression levels of many growth- 
related genes, including IGF2, $\mathrm{H} 19$ and $C D K N 1 C$. It also influences the transcriptional activity of KvDMR1, the ICR that controls the KCNQ1 domain (Arima et al., 2005; Varrault et al., 2006). This interesting finding places the imprinted genes involved in TNDM, BWS and SRS in a common regulatory network that influences intra-uterine growth.

Recently, another ICR was identified to be subject to 'epimutations' in humans. It concerns the DLK1-GTL2 imprinted domain on chromosome 14q32.2 (Fig. 5). This domain comprises both paternally and maternally expressed genes that are important for development and growth. Uniparental disomy for the paternal chromosome, UPD(14)pat, had been known to result in a typical phenotype with facial abnormalities, a small, bell-shaped thorax, polyhydramnios and abdominal wall defects. Kagami and co-workers (2008) identified several rare cases of people without uniparental disomy who showed a very similar phenotype, particularly the manifestation of a bell-shaped thorax with a 'coathanger appearance' of the ribs in the neonatal period. In three of these patients, there was also no evidence for gene deletions in this large domain, and the authors therefore focused their attention on the paternally methylated ICR (IG-DMR) of this domain. In the three patients without genetic defects the ICR showed methylation on the maternal allele as well. This biallelic methylation correlated with excessively high levels of expression of $R T L 1$, one of the paternally expressed genes of the domain which is thought to be involved in the paternal up(14)-like clinical phenotype (Kagami et al., 2008).

Maternal UPD(14) is associated with a different set of phenotypic manifestations. A recent study identified a single patient with maternal UPD(14)-like clinical phenotypes in whom an epigenetic mutation had occurred at the ICR (Temple et al., 2007). Interestingly, this epigenetic change was the exact mirror image of the epimutations leading to the UPD(14) pat-like phenotypes: a loss of the paternal methylation at the IG-DMR such that now both the alleles were unmethylated (Fig. 5). The resulting decreased expression of DLK1 at the DLK1-GTL2 domain is thought to contribute to this clinical phenotype (Kagami et al. 2008).

When do the pathological epimutations at ICRs arise? This is difficult to determine, but is thought to occur early in development. This idea follows firstly from the observed broad presence of epimutations throughout the body in patients, and from cases of monozygotic twins of whom only one of the two had the epimutation (Delaval et al., 2006). At a low frequency -these are rare sporadic diseases- maintenance of the differential DNA methylation at ICRs is perturbed during early pregnancy, presumably in a stochastic manner. In most cases, this process affects individual ICRs, but it was observed in cases of TNDM and BWS that multiple ICRs were affected at the same time (Mackay et al., 2006; Mackay et al., 2008; Bliek et al., 2008). Altered methylation states persist through subsequent development and this leads to different disease phenotypes depending on which imprinted domain(s) is affected.

The occurrence of epimutations is significantly increased when early embryos are taken from their natural environment, and are subjected to the stress of in vitro culture. It has been shown in the mouse, that pre-implantation embryo culture frequently leads to aberrant DNA methylation at the IGF2-H19 ICR and other ICRs, and that this has phenotypic consequences for subsequent development in vivo (Khosla et al., 2001; Mann et al., 2004; Rivera et al., 2008). Similar culture effects have been reported in early ovine embryos (Young et al., 2001). It is not clear whether the mechanisms underlying the culture-induced perturbation of ICRs are the same as for the epimutations in BWS, SRS, and TNDM, and the thorax abnormalities linked to chromosome 14q32. Nevertheless, the in vitro work highlights the possibility that also in humans, culture and manipulation could lead to epimutations at ICRs with long-lasting phenotypic consequences. This question would be particularly pertinent for assisted reproduction technologies (ART). Based on initial studies on relatively small cohorts, it has been suggested that the frequency of imprinting-related diseases could be higher in babies conceived by ART as compared to naturally conceived babies (Arnaud and Feil, 2005). It should be important to determine whether this holds true in larger cohorts as well (Bowdin et al., 2007). Given that couples seeking assisted reproduction are compromised in their natural fertility, an alternative hypothesis for the occurrence of imprinting-related diseases in ART babies would be that defects in gametogenesis and reproduction interfere with the epigenetic regulation of imprinting. The recent demonstration of aberrant ICR methylation in oligospermic males (Marques 2004; Kobayashi et al., 2007; Marques 2008) indicates that this should be a promising theme for future research in reproduction.

\section{Acknowledgements}

$R F$ thanks members of the Imprinting and Development group for comments and discussion, acknowledges grant funding from the Agence National de Recherche (ANR, programme Blanc EMPREINTE), INCa (Institut National de Cancer), the ESF EUROCORES programme EuroSTELLS, and the Association de Recherche sur le Cancer (ARC) programme ARECA, and thanks the European Framework-6 network EPIGENOME for encouragement and support.

\section{References}

ADENOT, P.G., MERCIER, Y., RENARD, J-P. and THOMPSON, E.M. (1997) Differential $\mathrm{H} 4$ acetylation of paternal and maternal chromatin precedes DNA replication and differential transcriptional activity in pronuclei of 1-cell mouse embryos. Development 124: 4615-1625.

ARIMA, T., DREWELL, R.A., ARNET, K.L., INOUE, J., MAKIKA, Y., HATA, A. OSHIMURA, M., WAKE, N. and SURANI, M.A. (2001). A conserved imprinting control region at the HYMA1/ZAC domain is implicated in transient neonatal diabetes mellitus. Hum. Mol. Genet. 10: 1475-1483.

ARIMA, T., KAMIKIHARA, T., HAYASHIDA, T., KATO, K., INOUE, T., SHIRAYOSHI, Y., OSHIMURA, M., SOEJIMA, H., MUKAI, T. and WAKE, N. (2005). ZAC, LIT1 (KCNQ1OT1) and p57KIP2 (CDKN1C) are in an imprinted gene network that may play a role in Beckwith-Wiedemann syndrome. Nucl. Acids Res. 33: 26502660.

ARNAUD, P. and FEIL, R. (2005). Epigenetic deregulation of genomic imprinting in human disorders and following assisted reproduction. Birth Defect Research. Part C: Embryo Today 75: 81-97.

BARLOW, D.P., STÖGER, R., HERRMANN, B.G., SAITO, K. and SCHWEIFER, N. (1991). The mouse insulin-like growth factor type-2 receptor is imprinted and closely linked to the Tme locus. Nature 349: 84-87.

BARTON, S.C., ARNEY, K.L., SHI, W., NIVELEAU, A., FUNDELE, R., SURANI, M.A. and HAAF, T. (2001). Genome-wide methylation patterns in normal and uniparental early mouse embryos. Hum. Mol. Genet. 10: 2983-2987.

BEAUJEAN, N., HARTSHORNE, G., CAVILLA, J., TAYLOR, J., GARDNER, J., WILMUT, I., MEEHAN, R. and YOUNG, L. (2004). Non-conservation of mammalian preimplantation methylation dynamics. Curr. Biol. 14: R226-227.

BLIEK, J., TERHAL, P., VAN DEN BOGAARD, M.J., MAAS, S., HAMEL, B., SALIEB-BEUGELAAR, G., SIMON, M., LETTEBOER, T., VAN DER SMAGT, J., KROES, H. and MANNENS, M. (2006). Hypomethylation of the H19 gene 
causes not only Silver-Russell syndrome, but also isolated asymmetry or a SRS-like phenotype. Am. J. Hum. Genet. 78: 604-614.

BLIEK, J., VERDE, G., CALLAWAY, J., MAAS, S.M., DE CRESCENZO, A., SPARAGO, A., CERRATO, F., RUSSO, S., FERRAIUOLO, S., RINALDI, M.M., FISCHETTO, R., LALATTA, F., GIORDANO, L., FERRARI, P., CUBELLIS, M.V., LARIZZA, L., TEMPLE, I.K., MANNENS, M.M., MACKAY, D.J. and RICCIO, A. (2009). Hypomethylation at multiple maternally methylated imprinted regions including PLAGL1 and GNAS loci in Beckwith-Wiedemann syndrome. Eur J Hum Genet. (doi:10.1038/ejhg.2008.233).

BOURC'HIS, D., XU, G.-L., LIN, C.-S., BOLLMAN, B. and BESTOR, T.H. (2001). Dnmt3L and the establishment of maternal genomic imprints. Science 294: 2536-2539.

BOWDIN, S., BRUETON, L., ALLEN, C., HARRISON, R., KIRBY, G., MAHER, E.R., AFNAN, M., KIRKMAN-BROWN, J., BARRATT, C. and REARDON, W. (2007). A survey of assisted reproduction technology births and imprinting disorders. Hum. Reprod. 22: 3237-3240.

CATTANACH, B.M. and KIRK, M. (1985). Differential activity of maternally and paternally derived chromosome regions in mice. Nature 315: 496-498.

CHAILLET, J.R., VOGT, T.F., BEIER, D.R. and LEDER, P. (1991) Parental-specific methylation of an imprinted transgene is established during gametogenesis and progressively changes during embryogenesis. Cell 66: 77-83.

CROPLEY, J.E., SUTER, C.M., BECKMAN, K.B. and MARTIN, D.I.K. (2006). Germ-line epigenetic modification of the murine Avy allele by nutritional complementation. Proc. Natl. Acad. Sci. USA 103: 17308-17312.

DEAN, W., SANTOS, F., STOJKOVIC, M., ZAHARTCHENKO, V., WALTER, J., WOLF, E. and REIK, W. (2001). Conservation of methylation reprogramming in mammalian development: aberrant reprogramming in cloned embryos. Proc. Natl. Acad. Sci. USA 98: 13734-13738.

DELAVAL, K. and FEIL, R. (2004) Epigenetic regulation of mammalian genomic imprinting. Curr. Opin. Genet. Dev. 14: 188-195.

DELAVAL, K., WAGSCHAL, A., and FEIL, R. (2006). Epigenetic deregulation of imprinting in congenital diseases of aberrant growth. BioEssays 28: 453-459.

DELAVAL, K., GOVIN, J., CERQUEIRA, F, ROUSSEAUX, S., KHOCHBIN, S. and FEIL, R. (2007). Differential histone modifications mark mouse imprinting control regions during spermatogenesis. EMBO J. 26: 720-729

DIAZ-MEYER, N., DAY, C.D., KHATOD, K., MAHER, E.R., COOPER, W., REIK, W., JUNIEN, C., GRAHAM, G., ALGAR, E., DER KALOUSTIAN, V.M., and HIGGINS, M.J. (2003). Silencing of CDKN1C (p57KIP2) is associated with hypomethylation at KvDMR1 in Beckwith-Wiedemann syndrome. J. Med. Genet. 40: 797-801

DOHERTY, A.S., MANN, M.R., TREMBLAY, K.D., BARTOLOMEI, M.S., and SCHULTZ, R.M. (2000). Differential effects of culture on imprinted H19 expression in the preimplantation mouse embryo. Biol. Reprod. 62: 1526-1535.

EDWARDS, R.G. (2007). The significance of parthenogenetic virgin mothers in bonnethead sharks and mice. Reprod. Biomed. Online 15: 12-15.

EDWARDS, C.A. and FERGUSON-SMITH, A.C. (2007). Mechanisms regulating imprinted genes in clusters. Curr. Opin. Cell Biol. 19: 281-289.

EGGERMANN, T, SCHONHERR, N, MEYER, E, OBERMANN, C, MAVANY, M, EGGERMANN, K., RANKE, M.B. and WOLLMANN, H.A. (2006).'Epigenetic mutations in $11 \mathrm{p} 15$ in Silver-Russell syndrome are restricted to the telomeric imprinting domain. J. Med. Genet. 43: 615-616.

FEIL, R. (2006). Environmental and nutritional effects of the epigenetic regulation of genes. Mutation Res. 600: 46-57.

FLANAGAN, J.M., POPENDIKYTE, V., POZDNIAKOVAITE, N., SOBOLEV, M., ASSADZADEH, A., SCHUMACHER, A., ZANGENEH, M., LAU, L., VIRTANEN, C., WANG, S.C. and PETRONIS, A. (2006). Intra- and interindividual epigenetic variation in human germ cells. Am. J. Hum. Genet. 79: 67-84.

FOURNIER, C., Goto, Y., BALlestaR, E., DELAVAl, K., HEVER, A.M., ESTELLER, M. and FEIL, R. (2002). Allele-specific histone lysine methylation marks regulatory regions at imprinted mouse genes. EMBO J. 21: 6560-6570.

FULKA, H., MRAZEK, M., TEPLA, O. and FULKA, J. JR. (2004). DNA methylation pattern in human zygotes and developing embryos. Reproduction 128: 703708.

GARDNER, RJ, MACKAY, DJG, MUNGALL, AJ, POLYCHRONAKOS, C, SIEBERT, R, SHIELD, J.P., TEMPLE, I.K. and ROBINSON, D.O. (2000). An imprinted locus associated with transient neonatal diabetes mellitus. Hum. Mol. Genet. 9:
589-596.

GICQUEL, C., ROSSIGNOL, S., CABROL, S., HOUANG, M., STEUNOU, V., BARBU, V., DANTON, F., THIBAUD, N., LE MERRER, M., BURGLEN, L., BERTRAND, A.M., NETCHINE, I. and LE BOUC, Y. (2005). Epimutation of the telomeric imprinting center region on chromosome 11p15 in Silver-Russell syndrome. Nature Genet. 37: 1003-1007.

GOVIN, J., CARON, C., LESTRAT, C., ROUSSEAUX, S. and KHOCHBIN, S. (2004). The role of histones in the chromatin remodelling during mammalian spermiogenesis. Eur. J. Biochem. 271: 3459-3469.

GOVIN, J., ESCOFFIER, E., ROUSSEAUX, S., KUHN, L., FERRO, M., THÉVESON, J., CATENA, R., DAVIDSON, I., GARIN, J., KHOCHBIN, S., and CARON, C. (2007). Pericentric heterochromatin reprogramming by new histone variants during mouse spermiogenesis. J. Cell. Biol. 176: 283-294.

GRAHAM, C.F. (1974). Production of parthenogenetic mammalian embryos and their use in biological research. Biol. Rev. Camb. Philos.Soc. 49: 399-424.

GROOT, T.V, BRUINS, E. and BREEUWER, J.A. (2003) Molecular genetic evidence for parthenogenesis in the Burmese python, Python molurus bivattatus. Heredity 90: 130-135.

HALES, F.D., WILSON, A.C., SLOANE, M.A., SIMON, J.C., LE GALLIC, J.F. and SUNNUCKS, P. (2002). Lack of detectable genetic recombination on the $X$ chromosome during parthenogenetic production of female and male aphids. Genet. Res. 79: 203-209.

HAGEMANN, L.J., PETERSON, A.J., WEILERT, L.L., LEE,R.S. and TERVIT, H.R. (1998). In vitro and and early in vivo development of sheep gynogenones and putative androgenones. Mol. Reprod. Dev. 50: 154-162.

HATA, K., OKANO, M., LEI, H. and LI, E. (2002). Dnmt3L cooperates with the Dnmt3 family of de novo DNA methyltransferases to establish maternal imprints in mice. Development 129: 1983-1993.

HIRASAWA, R., CHIBA, H., KANEDA, M., SHOJI, T., LI, E., JAENISCH, R. and SASAKI, H. (2008). Maternal and zygotic Dnmt1 are necessary and sufficient for the maintenance of DNA methylation imprints during preimplantation development. Genes Dev. in the press

HUTTER, B., HELMS, V. and PAULSEN, M. (2006). Tandem repeats in the CpG islands of imprinted genes. Genomics 88: 323-332.

JELENIC, P., STEHLE, J-C. and SHAW, P. (2006). The testis-specific factor CTCFL cooperates with the protein methyltransferase PRMT7 in H19 imprinting control region methylation. PLOS Biol. 4: e355.

JIRTLE, R.L. and SKINNER, M.K. (2007). Environmental epigenomics and disease susceptibility. Nature Rev. Genet. 8: 253-262.

KAGAMI, M., SEKITA, Y., NISHIMURA, G., IRIE, M., KATO, F., OKADA, M., YAMAMORI, S., KISHIMOTO, H., NAKAYAMA, M., TANAKA, Y., MATSUOKA K., TAKAHASHI, T., NOGUCHI, M., TANAKA, Y., MASUMOTO, K., UTSUNOMIYA, T., KOZUAN, H., KOMATSU, Y., OHASHI, H., KUROSAWA, K., KOSAKI, K., FERGUSON-SMITH, A.C., ISHINO, F. and OGATA, T. (2008). Deletions and epimutations affecting the human $14 q 32.2$ imprinted region in individuals with paternal and maternal upd(14)-like phenotypes. Nature Genet. 40: 237-242.

KANEDA, M., OKANO, M., HATA, K., SADO, T., TSUJIMOTO, N., LI, E. and SASAKI, H. (2004). Essential role for de novo DNA methyltransferase Dnmt3a in paternal and maternal imprinting. Nature 429: 900-903.

KAWAHARA, M., WU, Q., TAKAHASHI, N., MORITA, S., YAMADA, K., ITO, M. FERGUSON-SMITH, A.C. and KONO, T. (2007). High frequency generation of viable mice from engineered bi-maternal embryos. Nat. Biotechnol. 25: 10451050.

KHOSLA, S., DEAN, W., BROWN, D., REIK, W., and FEIL, R. (2001). Culture of preimplantation mouse embryos affects fetal development and the expression of imprinted genes. Biol. Reprod. 64: 918-926.

KIMMINS, S. and SASSONI-CORSI, P. (2005). Chromatin remodelling and epigenetic features of germ cells. Nature 434: 583-589.

KOBAYASHI, H., SUDA, C., ABE, T., KOHARA, Y., IKEMURA, T. and SASAKI, H. (2006). Bisulfite sequencing and dinucleotide content analysis of 15 imprinted mouse differentially methylated regions (DMRs): paternally methylated DMRs contain less CpGs than maternaly methylated DMRs. Cytogenet. Genome Res. 113: $130-137$.

KOBAYASHI, H., SATO, A., OTSU, E., HIURA, H., TOMATSU, C., UTSUNOMIYA, T., SASAKI, H., YAEGASHI, N. and ARIMA, T. (2007). Aberrant DNA methyla- 
tion of imprinted loci in sperm from oligospermic patients. Hum. Mol. Genet. 16: 2542-2551.

KONO, T., OBATA, Y., WU, Q.L., NIWA, K., ONO, Y., YAMAMOTO, Y., PARK, E.S., SEO, J.S. and OGAWA, H. (2004). Birth of parthenogenetic mice that can develop to adulthood. Nature 428: 860-864.

KONO, T. (2006). Genomic imprinting is a barrier to parthenogenesis in mammals. Cytogenet. Genome Res. 113: 31-35.

KURIHARA, Y., KAWAMURA, Y., UCHIJIMA, Y., AMAMO, T., KOBAYASHI, H., ASANO, T. and KURIHARA, H. (2008). Maintenance of genomic methylation patterns during preimplantation development requires the somatic form of DNA methyltransferase-1. Dev. Biol. 313: 335-346.

LANE, N., DEAN, W., ERHARDT, S., HAJKOVA, P., SURANI, A., WALTER, J. and REIK, W. (2003). Resistance of IAPs to methylation reprogramming may provide a mechanism of epigenetic inheritance in the mouse. Genesis 35: 8893.

LATHAM, K.E., DOHERTY, A.S., SCOTT, C.D. and SCHULTZ, R.M. (1994). Igf2r and Igf2 expression in androgenetic, gynogenetic, and parthenogenetic preimplantation mouse embryos: absence of regulation by genomic imprinting. Genes Dev. 8: 290-299.

LEE, M.P., DEBAUN, M.R., MITSUYA, K., GALONEK, H.L., BRANDENBURG, S., OSHIMURA, M. and FEINBERG, A.P. (1999). Loss of imprinting of a paternally expressed transcript, with antisense orientation to KVLQT1, occurs frequently in Beckwith-Wiedemann syndrome and is independent of insulin-like growth factor II imprinting. Proc. Natl. Acad. Sci. USA 96: 5203-5208.

LEPIKHOV, K., ZAKHARTCHENKO, V., HAO, R., YANG, F., WRENZYCKI, C., NIEMANN, H., WOLF, E. and WALTER, J. (2008). Evidence for conserved DNA and histone $\mathrm{H} 3$ methylation reprogramming in mouse, bovine and rabbit zygotes. Epigenetics Chromatin. 1: 8.

LI, E., BEARD, C. and JAENISCH, R. (1993). Role for DNA methylation in genomic imprinting. Nature 366: 362-365.

LUCIFERO, D., MANN, M.R., BARTOLOMEI, M.S. and TRASLER, J.M. (2004). Gene-specific timing and epigenetic memory in oocyte imprinting. Hum. Mol. Genet. 13: 839-849.

MACKAY, D.J., HAHNEMANN, J.M., BOONEN, S.E., POERKSEN, S., BUNYAN, D.J., WHITE, H.E., DURSTON, V.J., THOMAS, N.S., ROBINSON, D.O., SHIELD, J.P., CLAYTON-SMITH, J. and TEMPLE, I.K. (2006). Epimutation of the TNDM locus and the Beckwith-Wiedemann syndrome centromeric locus in individuals with transcrient neonatal diabetes mellitus. Hum. Genet. 119: 179-184.

MACKAY, D.J., CALLAWAY, J.L., MARKS, S.M., WHITE, H.E., ACERINI, C.L., BOONEN, S.E., DAYANIKLI, P., FIRTH, H.V., GOODSHIP, J.A., HAEMERS, A.P., HAHNEMANN, J.M., KORDONOURI, O., MASOUD, A.F., OESTERGAARD, E., STORR, J., ELLARD, S., HATTERSLEY, A.T., ROBINSON, D.O. AND TEMPLE, I.K. (2008). Hypomethylation of multiple imprinted loci in individuals with transient neonatal diabetes is associated with mutations in ZFP57. Nat. Genet. 40: 949-951.

MANN, J.R. and LOVELLBADGE, R.H. (1984). Inviability of parthenogenones is determined by pronuclei, not egg cytoplasm. Nature 310: 66-67.

MANN, M.R., LEE, S.S., DOHERTY, A.S., VERONA, R.I., NOLEN, L.D., SCHULTZ, R.M., and BARTOLOMEI, M.S. (2004). Selective loss of imprinting in the placenta following preimplantation development in culture. Development 131: 3727-3735.

MARQUES, C.J., CARVALHO, F., SOUSA, M. and BARROS, A. (2004). Genomic imprinting in disruptive spermatogenesis. Lancet 363: 1700-1702.

MARQUES, C.J., COSTA, P., VAZ, B., CARVALHO, F., FERNANDES, S., BARROS, A. and SOUSA, M. (2008). Abnormal methylation of imprinted genes in human sperm is associated with oligozoospermia. Mol. Hum. Reprod. 14:67-74.

MARTENS, J.H.A., O'SULLIVAN, R.J., BRAUNSCHWEIG, U., OPRAVIL, S., RADOLF, M., STEINLEIN, P. and JENUWEIN, T. (2005). The profile of repeatassociated histone lysine methylation states in the mouse epigenome. EMBO J. 24: $800-812$.

MAYER, W., NIVELEAU, A., WALTER, J., FUNDELE, R. and HAAF, T. (2000). Embryogenesis - Demethylation of the zygotic paternal genome. Nature 403: 501-502.

MCGRATH, J. and SOLTER, D. (1984). Completion of mouse embryogenesis requires both the maternal and paternal genomes. Cell 37: 179-183.

MCMINN J, WEI M, SCHUPF N, CUSMAI J, JOHNSON EB, et al. (2006).
Unbalanced placental expression of imprinted genes in human intrauterine growth restriction. Placenta 27: 540-549.

MORGAN, H.D., SUTHERLAND, H.G., MARTIN, D.I. and WHITELAW, E. (1999). Epigenetic inheritance at the agouti locus in the mouse. Nature Genet. 23: 314318.

MORGAN, H.D., SANTOS, F., GREEN, K., DEAN, W. and REIK, W. (2005) Epigenetic reprogramming in mammals. Hum. Mol. Genet. 14, Spec No 1: R4758.

MORISON, I.M., RAMSAY, J.P. and SPENCER, H.G. (2005). A census of mammalian imprinting. Trends Genet. 21: 457-465.

NAKAMURA, T., ARAI, Y., UMEHARA, H., MASUHARA, M., KIMURA, T. TANIGUCHI, H., SEKIMOTO, T., IKAWA, M., YONEDA, Y., OKABE, M. TANAKA, S., SHIOTA, K. and NAKANO, T. (2007). PGC7/Stella protects against DNA demethylation in early embryogenesis. Nature Cell Biol. 9: 64-71.

NIWA, K., TAKANO, R., OBATA, Y., HIURA, H., KOMIYAMA, J., OGAWA, H. and KONO, T. (2004) Nuclei of oocytes from mouse parthenogenetic embryos are competent to support development to term. Biol. Reprod. 71: 1560-1570.

OAKES, C.C., LA SALLE, S., SMIRAGLIA, D.J., ROBAIRE, B. and TRASLER, J.M. (2007) Developmental acquisition of genome-wide DNA methylation occurs prior to meiosis in male germ cells. Dev. Biol. 307: 368-379.

OBATA, Y. and KONO, T. (2002). Maternal primary imprinting is established at a specific time for each gene throughout oocyte growth. J. Biol. Chem. 277: 52855289.

OLEK, A. and WALTER, J. (1997). The pre-implantation ontogeny of the H19 methylation imprint. Nature Genet. 17: 275-276.

OLSEN, M.W. (1960) Performance record of a parthenogenetic turkey male Science 132: 1661

OOI, S.K., QIU, C., BERNSTEIN, E., LI, K., JIA, D., YANG, Z., ERDJUMENTBROMAGE, H., TEMPST, P., LIN, S.P., ALLIS, C.D., CHENG, X. and BESTOR, T.H. (2007). DNMT3L connects unmethylated lysine 4 of histone $\mathrm{H} 3$ to de novo methylation of DNA. Nature 448: 714-717.

OSWALD, J., ENGEMANN, S., LANE, N., MAYER, W., OLEK, A., FUNDELE, R., DEAN, W., REIK, W. and WALTER, J. (2000). Active demethylation of the paternal genome in the mouse zygote. Curr. Biol. 10: 475-478.

PANNETIER, M., JULIEN, E., SCHOTTA, G., TARDAT, M., SARDET, C. JENUWEIN, T. and FEIL, R. (2008). PR-SET7 and SUV4-20H regulate $\mathrm{H} 4$ lysine-20 methylation at imprinting control regions in the mouse. EMBO Reports 9: $998-1005$

PAULER, F.M., KOERNER, M.V. and BARLOW, D.P. (2007). Silencing by imprinted noncoding RNAs: is transcription the answer? Trends Genet. 23: 284292.

PAYER, B., SAITOU, M., BARTON, S.C., THRESHER, R., DIXON, J.P., ZAHN, D., COLLEDGE, W.H., CARLTON, M.B., NAKANO, T. and SURANI, M.A. (2003) Stella is a maternal effect gene required for normal early development in mice. Curr. Biol. 13: 2110-2117.

PERK, J., MAKEDONSKI, K., LANDE, L., CEDAR, H., RAZIN, A. and SHEMER, R (2002). The imprinting mechanism of the Prader-Willi/Angelman regional control center. EMBO J. 21: 5870-5814.

REGHA, K., SLOANE, M.A., HUANG, R., PAULER, F.M., WARCZOK, K.E., MELIKANT, B., RADOLF, M., MARTENS, J.H., SCHOTTA, G., JENUWEIN, T. and BARLOW, D.P. (2007). Active and repressive chromatin are interspersed without spreading in an imprinted gene cluster in the mammalian genome. Mol. Cell 27: 353-366.

REIK, W., COLLICK, A., NORRIS, M.L., BARTON, S.C. and SURANI, M.A. (1987) Genomic imprinting determines methylation of parental alleles in transgenic mice. Nature 328: 248-251.

REIK, W., DEAN, W. and WALTER, J. (2001). Epigenetic reprogramming in mammalian development. Science 293: 1089-1093.

RIVERA, R.M., STEIN, P., WEAVER, J.R., MAGER, J., SCHULTZ, R.M. and BARTOLOMEI, M.S. (2007). Manipulations of mouse embryos prior to implantation result in aberrant expression of imprinted genes on day 9.5 of development. Hum. Mol. Gen. 17: 1-14.

ROUGIER, N., BOURC'HIS, D., GOMES, D.M., NIVELEAU, A., PLACHOT, M., PALDI, A. and VIEGAS-PEQUIGNOT, E. (1998). Chromosome methylation patterns during mammalian preimplantation development. Genes Dev. 12 2108-2113. 
ROUSSEAUX, S., CARON, C., GOVIN, J., LESTRAT, C., FAURE, A.K. and KHOCHBIN, S. (2005). Establishment of male-specific epigenetic information. Gene 345: 139-153.

SANTOS, F., HENDRICH, B., REIK, W. and DEAN, W. (2002). Dynamic reprogramming of DNA methylation in the early mouse embryo. Dev. Biol. 241: 172-182.

SARVELLA, P. (1973). Adult parthenogenetic chickens. Nature 23: 171.

SASAKI, H. and MATSUI, Y. (2008). Epigenetic events in mammalian germ-cell development: reprogramming and beyond. Nature Rev. Genet. 9: 129-140.

SCHAEFER, C.B., OOI, S.K., BESTOR, T.H. and BOURC'HIS, D. (2007). Epigenetic decisions in mammalian germ cells. Science 316: 398-399.

SHI, W., DIRIM, F., WOLF, E., ZAKHARTCHENKO, V. and HAAF, T. (2004). Methylation reprogramming and chromosomal aneuploidy in in vivo fertilized and cloned rabbit preimplantation embryos. Biol. Reprod. 71: 340-347.

SMILINICH, N.J., DAY, C.D., FITZPATRICK, G.V., CALDWELL, G.M., LOSSIE, A.C., COOPER, P.R., SMALLWOOD, A.C., JOYCE, J.A., SCHOFIELD, P.N., REIK, W., NICHOLLS, R.D., WEKSBERG, R., DRISCOLL, D.J., MAHER, E.R., SHOWS, T.B. and HIGGINS, M.J. (1999). A maternally methylated CpG island in KvLQT1 is associated with an antisense paternal transcript and loss of imprinting in Beckwith-Wiedemann syndrome. Proc. Natl. Acad. Sci. USA 96: 8064-8069.

STURM, K.S., FLANNERY, M.L. and PEDERSEN, R.A. (1994). Abnormal development of embryonic and extraembryonic cell lineages in parthenogenetic mouse embryos. Dev. Dyn. 201: 11-28.

SURANI, M.A. and BARTON, S.C. (1983). Development of gynogenetic eggs in the mouse: Implications for parthenogenetic embryos. Science 222: 1034-1036.

SURANI, M.A., BARTON, S.C. and NORRIS, M.L. (1984). Development of reconstituted mouse eggs suggests imprinting of the genome during gametogenesis. Nature 308: 548-550.

SWAIN, J.L., STEWART, T.A. and LEDER, P. (1987). Parental legacy determines methylation and expression of an autosomal transgene - a molecular mechanism for parental imprinting. Cell 50: 719-727.

TEMPLE, I.K., SHRUBB, V., LEVER, M., BULLMAN, H. and MACKAY, D.J. (2007). Isolated imprinting mutation of the DLK1/GTL2 locus associated with a clinical manifestation of maternal disomy of chromosome 14. J. Med. Genet. 44: 637640.

TORRES-PADILLA, M-E., BANNISTER, A.J., HURD, P.J., KOUZARIDES, T. and ZERNICKA-GOETZ, M. (2006). Dynamic distribution of the replacement histone variant H3.3 in the mouse zygote and preimplantation embryos. Int. J. Dev.
Biol. 50: 455-461.

UMLAUF, D., GOTO, Y., CAO, R., CERQUEIRA, F., WAGSCHAL, A., ZHANG, Y. and FEIL, R. (2004). Imprinting along the Kcnq1 domain on mouse chromosome 7 involves repressive histone methylation and recruitment of Polycomb group complexes. Nat. Genet. 36: 1296-1300.

VAN DER HEIJDEN, G.W., DIEKER, J.W., DERIJCK, A.A., MULLER, R., BERDEN, J.H., BRAAT, D.D., VAN DER VLAG, J. and DE BOER, P. (2005). Asymmetry in histone $\mathrm{H} 3$ variants and lysine methylation between paternal and maternal chromatin of the early embryo. Mech. Dev. 122: 1008-1022.

VARRAULT, A., BILANGES, B., MACKAY, D.J., BASYUK, E., AHR, B., FERNANDEZ, C., ROBINSON, D.O., BOCKAERT, J. and JOURNOT, L. (2001). Characterization of the methylation-sensitive promoter of the imprinted ZAC gene supports its role in transient neonatal diabetes mellitus. J. Biol. Chem. 276: 18653-18666.

VARRAUlt, A., Gueydan, C., DELALBRE, A., BELLMAN, A., HOUSSAMI, S., AKNIN, C., SEVERAC, D., CHOTARD, L., KAHLI, M., LE DIGARCHER, A., PAVLIDIS, P. and JOURNOT, L. (2006). Zac1 regulates an imprinted gene network critically involved in the control of embryonic growth. Dev. Cell 11: 711722.

VERONA, R.I., MANN, M.R. and BARTOLOMEI, M.S. (2003) Genomic imprinting: intricacies of epigenetic regulation in clusters. Annu. Rev. Cell Dev. Biol. 19: 237-259.

VU, T.H., LI, T. and HOFFMAN, A.R. (2004). Promoter-restricted histone code, not the differentially methylated DNA regions or antisense transcripts, marks the imprinting status of IGF2R in human and mouse. Hum. Mol. Genet. 13: 22332245.

WU, M.-Y., TSAI, T.-F. and BEAUDET, A.L. (2006). Deficiency of Rbp1/Arid4a and Rbbp1/1/Arid4b alters epigenetic modifications and suppresses an imprinting defect in the PWS/AS domain. Genes Dev. 20: 2859-2870.

WYKES, S.M. and KRAWETZ, S.A. (2003). The structural organisation of sperm chromatin. J. Biol. Chem. 278: 29471-29477.

YOON, B.J., HERMAN, H., SIKORA, A., SMITH, L.T., PLASS, C. and SOLOWAY, P.D. (2002) Regulation of DNA methylation of Rasgrf1. Nature Genet. 30: 9296.

YOUNG, L.E., FERNANDES, K., MCEVOY, T., BUTTERWITH, S.C., GUTIERREZ, C.G., CAROLAN, C., BROADBENT, P.J., ROBINSON, J.J., WILMUT, I. and SINCLAIR, K.D. (2001). Epigenetic change in IGF2R is associated with fetal overgrowth after sheep embryo culture. Nature Genet. 27: 153-154. 


\section{Further Related Reading, published previously in the Int. J. Dev. Biol.}

See our Special Issue Fertilization edited by Paul M. Wassarman and Victor D. Vacquier at: http://www.ijdb.ehu.es/web/contents.php?vol=52\&issue=5-6

Dynamic alterations of linker histone variants during development James S. Godde and Kiyoe Ura

Int. J. Dev. Biol. (2009) 53 (doi: 10.1387/ijdb.082644jg)

Unaltered imprinting establishment of key imprinted genes in mouse oocytes after in vitro follicle culture under variable follicle-stimulating hormone exposure Ellen Anckaert, Tom Adriaenssens, Sergio Romero, Sarah Dremier and Johan Smitz Int. J. Dev. Biol. (2009) 53 (doi: 10.1387/ijdb.082619ea)

Hypomethylation of paternal DNA in the late mouse zygote is not essential for development

Zbigniew Polanski, Nami Motosugi, Chizuko Tsurumi, Takashi Hiiragi and Steffen Hoffmann

Int. J. Dev. Biol. (2008) 52: 295-298

DNA methylation state is preserved in the sperm-derived pronucleus of the pig zygote

Young-Sun Jeong, Seungeun Yeo, Jung-Sun Park, Deog-Bon Koo, Won-Kyung Chang, Kyung-Kwang Lee and Yong-Kook Kang

Int. J. Dev. Biol. (2007) 51: 707-714

Histone methylation defines epigenetic asymmetry in the mouse zygote.

Katharine L Arney, Siqin Bao, Andrew J Bannister, Tony Kouzarides and M Azim Surani Int. J. Dev. Biol. (2002) 46: 317-320

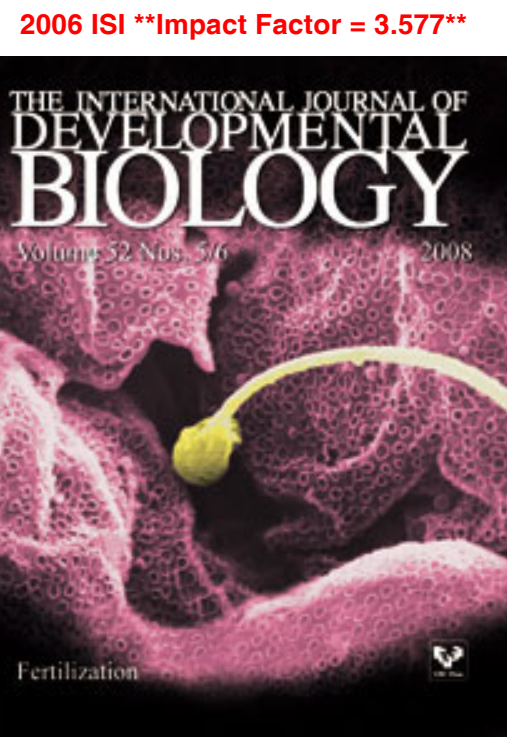

